\title{
ENRAIZAMENTO EX VITRO E ACLIMATIZAÇÃO DO PORTA-ENXERTO DE MACIEIRA MARUBAKAIDO MICROPROPAGADO ${ }^{1}$
}

\author{
SCHEILA DA CONCEIÇÃO MACIEL ${ }^{2}$; JOSÉ AFONSO VOLTOLINI ${ }^{3}$; ENIO LUIZ PEDROTTI ${ }^{4}$
}

\begin{abstract}
RESUMO - O objetivo deste trabalho foi avaliar a resposta ao enraizamento e à aclimatização do porta-enxerto de macieira Marubakaido micropropagado e submetido a diferentes substratos e condições de aclimatização antes da transferência para o viveiro. A indução ao enraizamento foi realizada ex vitro, imergindo $1,0 \mathrm{~cm}$ das bases das microestacas em uma solução de $1 \mathrm{~g} . \mathrm{L}^{-1}$ de AIB (ácido indolbutírico) durante 10 segundos. Os tratamentos utilizados foram de $0 ; 10 ; 15 ; 20$ e 30 dias na sala de aclimatização, com posterior transferência para a câmara de nebulização, ali permanecendo até completar 30 dias. Como substratos, foram utilizadas as combinações de Terra Roxa Estruturada e Vermicomposto (TRE:V) e Terra Roxa Estruturada e Casca de Arroz Carbonizada (TRE:CAC), na proporção de 1:1 (v:v). Após 30 dias, foram avaliados o enraizamento, a sobrevivência e o crescimento das mudas, que foram então transferidas para casa de vegetação. Após 60 dias de cultivo na casa de vegetação, foram avaliados o número de folhas e a altura da parte aérea, e, após 90 dias, foram repetidas as avaliações efetuadas aos 30 dias. Aos 30 dias, a percentagem de enraizamento no substrato TRE:V foi de $78 \%$ e no substrato TRE:CAC foi de 99\%. Essa percentagem diminuiu para 64\% no substrato TRE:V e $83 \%$ no substrato TRE:CAC aos 60 dias, e manteve-se estável aos 90 dias. O número médio de raízes foi maior em mudas que permaneceram 20 dias em sala de aclimatização e 10 dias em câmara de nebulização, com 16 raízes no tratamento que manteve 0 dia na sala de aclimatização e 30 dias na câmara de nebulização com 14 raízes. O maior crescimento médio das raízes $(8,2 \mathrm{~cm})$ aos 90 dias foi no substrato TRE:CAC. O substrato TRE:V possibilitou os melhores resultados médios para parte aérea. Os resultados obtidos indicam a possibilidade de enraizar este portaenxerto ex vitro, em substrato, simultaneamente com a aclimatização em câmara de nebulização.
\end{abstract}

Termos para indexação: Malus prunifolia, micropropagação, enraizamento ex vitro, AIB.

\section{ACCLIMATIZATION OF MICROPROPAGATED MARUBAKAIDO APPLE ROOTSTOCK}

\begin{abstract}
The purpose of this study was to evaluate the time required for the rooting and acclimatization of micropropagated Marubakaido rootstocks and the best time for their transfer to greenhouse conditions. Root induction was conducted ex vitro by immerging 0.5 to $1.0 \mathrm{~cm}$ of the rootstock bases in an IBA (indolebutyric acid) solution at $1.000 \mathrm{ppm}$ for 10 seconds. The treatments utilized were for $0,10,15,20$ or 30 days in the acclimatization room, with further transfer to the fog chamber, where they remained until completing a total of 30 days in the two environments. The substrates utilized were combinations of ultisoil and worm compost (TRE:V) and ultisoil and carbonized rice husks (TRE: CAC), in the proportion of 1:1 (v:v). After 30 days the survival and growth of the plants were evaluated, and they were then transferred to the green house. After 60 days in this condition, the number of leaves and the height of the aerial portion were evaluated, at 90 days the same parameters as at 30 days were evaluated. At 30 days the survival rate in the TRE:V substrate was $78 \%$ and in the TRE:CAC substrate $99 \%$. This rate decreased to $64 \%$ in the TR:V substrate and $83 \%$ in the TRE CAC: substrate at 60 days and remained stable until 90 days. The root number, presented the best result in the TRE:CAC 20 days in the acclimatization room and 10 days in spray. For the TRE:CAC substrate the best treatment was maintenance of the plants 10 days in the acclimatization room and 20 days in the fog.
\end{abstract}

Index terms: Malus prunifolia, micropropagation, ex vitro rooting, IBA.

\section{INTRODUÇÃO}

A cultura da macieira ocupa uma posição de destaque na economia do Estado de Santa Catarina, que é responsável por 60 $\%$ da maçã produzida no Brasil (ICEPA, 2000). A grande quantidade de mudas é produzida através de porta-enxertos produzidos pelo sistema de mergulhia de cepa. Esta técnica, no entanto, pode apresentar problemas ligados à transmissão de pragas e doenças.
A micropropagação é uma das técnicas que possibilita a produção em massa de genótipos superiores livres de pragas (Zimmermann e Fordham, 1985). Através dela, alguns protocolos regenerativos foram estabelecidos para vários porta-enxertos de macieira por Bolar et al. (1998) e Harbage et al. (1998). Apesar dos avanços nos protocolos, poucos trabalhos foram realizados no sentido de elucidar problemas ligados ao enraizamento e à aclimatização (Avanzato e Cherubini, 1993). Para Ziv (1995), o enraizamento e a aclimatização podem comprometer

1 (Trabalho 084/2001). Recebido: 11/04/2001. Aceito para publicação: 14/11/2001.

2 Eng ${ }^{\mathrm{a}}$ Agrônoma, Bolsista de IC (CNPq).

3 Eng ${ }^{\mathrm{o}}$ Agrônomo, MSc Laboratório de Morfogênese e Bioquímica Vegetal - Departamento de Fitotecnia CCA/Universidade Federal de Santa Catarina - Caixa Postal 476, CEP 88049-900 - Florianópolis, BR.

4 Engo Dr. Prof. Adjunto IV, Laboratório de Morfogênese e Bioquímica Vegetal, Departamento de Fitotecnia CCA/Universidade Federal de Santa Catarina - Caixa Postal 476, CEP 88049-900 - Florianópolis, BR. E-mail:pedrotti@cca.ufsc.br. Finep e CNPq 
o processo de micropropagação por envolverem a neoformação de um sistema radicular e a passagem para condições ex vitro. Quando transferidas para condições ex vitro, as mudas normalmente apresentam altas taxas de transpiração, em função da alta condutividade hidráulica de suas folhas (Brainerd e Fuchigami, 1981), o que, na maioria das situações, provoca elevado déficit hídrico, podendo provocar a morte das mudas (Díaz-Pérez et al., 1995).

A indução ao enraizamento pode ser realizada in vitro, em meios com maior porosidade (Jay-Allemand et al., 1992), ou ex vitro, em substratos porosos (Pedrotti e Voltolini, 1997). Em substratos porosos, a planta produz maior número de raízes secundárias, possibilitando um maior suprimento de água e nutrientes para a planta (McClelland et al., 1990). Para a utilização comercial, o sistema de micropropagação deve possibilitar altas taxas de proliferação, enraizamento, aclimatização, sobrevivência e crescimento inicial das mudas em casa de vegetação (Lê e Collet, 1991; Ziv, 1995).

O objetivo deste trabalho foi avaliar o efeito de dois substratos e de cinco combinações de períodos de exposição das microestacas em sala de aclimatização e em câmara de nebulização sobre o enraizamento e sobrevivência do porta-enxerto de macieira Marubakaido, enraizado ex vitro.

\section{MATERIAL E MÉTODOS}

O trabalho foi conduzido no Laboratório de Morfogênese Vegetal do Departamento de Fitotecnia da Universidade Federal de Santa Catarina. O porta-enxerto de macieira Marubakaido (Malus prunifolia) foi mantido in vitro através de repicagens sucessivas, a cada 45 dias, em meio MS (Murashige e Skoog, 1962), em sala de crescimento com temperatura de $27 \pm 2^{\circ} \mathrm{C}$, fotoperíodo de $16 \mathrm{~h}$ de luz, com intensidade luminosa de $30 \mathrm{mmol} . \mathrm{m}^{-}$ ${ }^{2} \cdot \mathrm{s}^{-1}$, conforme metodologia utilizada por Nunes et al. (1999).

Para a indução ao enraizamento, foram usadas microestacas com $4 \mathrm{~cm}$ de altura e 4 folhas. A indução foi realizada ex vitro, submergindo $1,0 \mathrm{~cm}$ da base de cada microestaca em solução de ácido indolbutírico (AIB) (Sygma), na concentração de 1 g.L. $\mathrm{L}^{-1}$, durante 10 segundos. Posteriormente, elas foram transplantadas para bandejas com alvéolos de $50 \mathrm{~mL}$ de capacidade, contendo um dos seguintes substratos: 1- Terra Roxa Estruturada e Casca de Arroz Carbonizada (TRE:CAC); e 2- Terra Roxa Estruturada e Vermicomposto de esterco bovino (TRE:V), ambos na proporção $1: 1(\mathrm{v}: \mathrm{v})$.

As bandejas foram colocadas em caixas plásticas cobertas com uma placa de vidro transparente, conforme metodologia utilizada por Pedrotti e Voltolini (1997). Esta condição permitiu a manutenção da umidade relativa em 100\%. As bandejas foram transferidas para sala de aclimatização com temperatura de $27 \pm 2^{\circ} \mathrm{C}$, intensidade luminosa de $30 \mathrm{mmol} \cdot \mathrm{m}^{-2} . \mathrm{s}^{-1}$ e fotoperíodo de $16 \mathrm{~h}$ de luz, onde permaneceram durante $10 ; 15 ; 20$ ou 30 dias, sendo que, num dos tratamentos, as bandejas foram transferidas diretamente para a câmara de nebulização. Após cada período de permanência na sala de aclimatização, as mudas foram transferidas para a câmara de nebulização, onde permaneceram até que cada tratamento completasse 30 dias, a partir da indução ao enraizamento.

Após o período de 30 dias, as mudas foram avaliadas nos seguintes parâmetros: a) porcentagem de enraizamento; b) número de raízes; c) comprimento médio das raízes; d) biomassa seca das raízes; e) número de folhas; e f) altura média da parte aérea. Após a avaliação, as raízes foram podadas a $1 \mathrm{~cm}$ da base das microestacas, e as mudas foram imediatamente transferidas para bandejas com alvéolos de $100 \mathrm{~mL}$ de capacidade, sem alteração da composição dos substratos. As bandejas permaneceram mais 10 dias na câmara de nebulização, sendo então transferidas para casa de vegetação. Depois de 60 dias de cultivo em casa de vegetação, foram avaliados a sobrevivência das mudas, o número de folhas e a altura da parte aérea, e aos 90 dias, foram avaliados os mesmos parâmetros que haviam sido avaliados aos 30 dias.

O delineamento experimental utilizado foi um bifatorial e um trifatorial, com 4 repetições e 10 mudas por repetição. A análise dos dados foi efetuada segundo Sokal \& Rohlf (1995), através do programa de computador STATGRAFICS. Quando foram detectados efeitos significativos, a comparação de médias foi realizada pelo teste de SNK, a 5\% de probabilidade.

\section{RESULTADOS E DISCUSSÃO}

Enraizamento - As altas percentagens de enraizamento obtidas em mudas tratadas com AIB e posteriormente transferidas para o substrato TRE:CAC (Tabela 1) indicam que esta metodologia é adequada para a indução de raízes neste porta-enxerto e confirmam a hipótese de Lê e Collet (1991), segundo a qual, o tempo necessário para a indução de raízes pode ser pequeno, dependendo da condição fisiológica do genótipo utilizado. Provavelmente, as condições fisiológicas deste porta-enxerto, aliadas às condições experimentais utilizadas, favoreceram a indução de raízes, como foi observado por Lane e McDougald (1982) em outros porta-enxertos de macieira. Além disto, o tipo, a concentração e o tempo de exposição à auxina, utilizados neste trabalho, não induziram à formação de calos.

Aos 30 dias após a transferência ex vitro, a percentagem de enraizamento foi maior nas mudas que foram aclimatadas no substrato TRE:CAC (Tabela 1), provavelmente devido às suas características físicas, já que a casca de arroz carbonizada aumenta o espaço poroso, como foi observado por Lê e Collet (1991) e por Avanzato e Cherubini (1993). O substrato TRE:V apresenta menor porosidade e maior retenção de água, o que certamente diminui o espaço de aeração e, por conseguinte, a percentagem de enraizamento. No substrato TRE:CAC, as raízes mostraram uma tendência em aumentar seu comprimento (Tabela 1). Este substrato contém menos nutrientes do que o TRE:V, visto que a casca de arroz contribuiu menos do que o vermicomposto de esterco de bovinos no aporte de nutrientes aos substratos utilizados. Esses resultados são semelhantes aos obtidos por Lê e Collet (1991), que observaram maior comprimento das raízes em substratos com menores teores de nutrientes. Provavelmente, esta condição obriga a planta a mudar sua estratégia e deslocar maiores quantidades de carboidratos para o crescimento das raízes, a fim de garantir um maior suprimento de água e nutrientes. Díaz-Pérez et al. (1995) também obtiveram raízes maiores e com maior número de raízes secundárias quando utilizaram substratos porosos, pois estes possibilitam maior exploração de água e nutrientes. Neste sentido, Wraigth e Wraight

Rev. Bras. Frutic., Jaboticabal - SP, v. 24, n. 2, p. 289-292, agosto 2002 
(1998) salientam que a porosidade, a capacidade de retenção de água e o fornecimento de nutrientes, além da aeração, determinam a arquitetura do sistema radicular, o crescimento da planta e sua adaptação às condições mesológicas.

As raízes retomaram o crescimento após a poda radicular realizada aos 30 dias. Isto ocorreu a partir da emissão de raízes laterais, o que garantiu a sobrevivência das mudas segundo o substrato e o tempo de permanência nos dois ambientes (Tabela 2). A retomada de crescimento das raízes, observada neste trabalho, confirma as observações de Gribaudo et al. (1995), segundo os quais, os danos são os responsáveis pela morte das raízes e não sua transferência para a casa de vegetação, como foi preconizado por McClelland et al. (1990).

Aclimatização - As altas percentagens de enraizamento, que coincidem com as de sobrevivência, pois todas as plantas que enraizaram, sobreviveram, e as de crescimento das mudas (Tabe- las 1 e 2) sugerem que a umidade relativa nos ambientes estudados garantiu as condições adequadas para a aclimatização e retomada de crescimento após a aclimatização das mudas. Esta hipótese é corroborada por Campostrini e Otoni (1996), pois plântulas produzidas in vitro não estão adaptadas ao novo ambiente, pois não possuem mecanismos de proteção contra a desidratação, já que seus estômatos geralmente se encontram abertos (Schackel et al., 1990). No entanto, segundo Pospíslová et al.(1997) e Bolar et al. (1998), durante a aclimatização, as mudas ativam os mecanismos que permitem sua sobrevivência após a transferência para a casa de vegetação. Possivelmente, as condições de aclimatização utilizadas neste trabalho possibilitaram a sobrevivência da planta até a entrada em funcionamento dos estômatos, o que permitiu um maior controle sobre as perdas de água, o que está de acordo com Sutter (1988).

TABELA 1 - Percentagem de enraizamento, biomassa seca e comprimento médio das raízes do porta-enxerto de macieira Marubakaido (Malus prunifolia) micropropagado, enraizado ex vitro nos substratos: Terra Roxa Estruturada (TRE):Vermicomposto (V) (1:1, v:v) e Terra Roxa Estruturada (TRE): Casca de Arroz Carbonizada (CAC) (1:1, v:v).

\begin{tabular}{|c|c|c|c|c|c|c|c|}
\hline \multirow[t]{3}{*}{ Substratos } & \multicolumn{3}{|c|}{ Enraizamento $(\%)$} & \multicolumn{2}{|c|}{$\begin{array}{c}\text { Biomassa seca das raízes } \\
(\mathrm{g})\end{array}$} & \multicolumn{2}{|c|}{$\begin{array}{l}\text { Comprimento médio das raízes } \\
\qquad(\mathrm{cm})\end{array}$} \\
\hline & \multicolumn{7}{|c|}{ Dias após a transferência para condições ex vitro } \\
\hline & 30 & 60 & 90 & 30 & 90 & 30 & 90 \\
\hline TRE:V & $77,50 \mathrm{~b}$ & $63,50 \mathrm{~b}$ & $63,50 \mathrm{~b}$ & $0,034 \mathrm{a}$ & $0,23 \mathrm{a}$ & $2,60 \mathrm{a}$ & $7,20 \mathrm{~b}$ \\
\hline TRE:CAC & $99,00 \mathrm{a}$ & 83,00 a & $83,00 \mathrm{a}$ & $0,070 \mathrm{a}$ & $0,25 \mathrm{a}$ & $3,20 \mathrm{a}$ & $8,20 \mathrm{a}$ \\
\hline $\mathrm{CV}(\%)$ & 13,40 & 16,10 & 16,10 & 80,00 & 17,50 & 53,70 & 20,20 \\
\hline
\end{tabular}

* Médias seguidas da mesma letra, dentro da coluna, não diferem significativamente, pelo teste de SNK, a 5\% de probabilidade.

TABELA 2 - Número de raízes, número de folhas e altura da parte aérea do porta-enxerto de macieira Marubakaido (Malus prunifolia) micropropagado, enraizado ex vitro, em diferentes combinações entre ambiente e substratos. Análise trifatorial no tempo.

\begin{tabular}{|c|c|c|c|c|c|c|c|c|c|}
\hline \multirow[b]{3}{*}{ Ambientes } & \multirow[b]{3}{*}{ Substratos } & \multicolumn{2}{|c|}{ Número de raízes } & \multicolumn{3}{|c|}{ Número de folhas } & \multicolumn{3}{|c|}{ Altura Parte Aérea $(\mathrm{cm})$} \\
\hline & & \multicolumn{8}{|c|}{ Dias após a transferência ex vitro } \\
\hline & & 30 & 60 & 30 & 60 & 90 & 30 & 60 & 90 \\
\hline \multirow[t]{2}{*}{$30 \mathrm{~N}$} & TRE:V & $7,0 \mathrm{~b}$ & $14,0 \mathrm{ab}$ & $8,0 \mathrm{~d}$ & $11,0 \mathrm{~b}$ & $15,0 \mathrm{ab}$ & $2,3 \mathrm{a}$ & $5,1 \mathrm{ab}$ & $9,3 \mathrm{a}$ \\
\hline & TRE:CAC & $8,0 \mathrm{ab}$ & $13,0 \mathrm{~b}$ & $8,0 \mathrm{~d}$ & $11,0 \mathrm{ab}$ & $12,0 \mathrm{~d}$ & $1,9 \mathrm{a}$ & $4,9 \mathrm{abc}$ & $7,3 \mathrm{~cd}$ \\
\hline \multirow[t]{2}{*}{$10 \mathrm{SA} / 20 \mathrm{~N}$} & TRE:V & $8,0 \mathrm{ab}$ & $13,0 \mathrm{~b}$ & $9,0 \mathrm{~cd}$ & $13,0 \mathrm{a}$ & $15,0 \mathrm{abc}$ & $2,1 \mathrm{a}$ & $4,3 \mathrm{bc}$ & $9,1 \mathrm{ab}$ \\
\hline & TRE:CAC & $9,0 \mathrm{ab}$ & $13,0 \mathrm{~b}$ & $12,0 \mathrm{a}$ & $13,0 \mathrm{a}$ & $15,0 \mathrm{abc}$ & $2,2 \mathrm{a}$ & $5,4 \mathrm{a}$ & $7,7 \mathrm{~cd}$ \\
\hline \multirow[t]{2}{*}{$15 \mathrm{SA} / 15 \mathrm{~N}$} & TRE:V & $8,0 \mathrm{ab}$ & $12,0 \mathrm{~b}$ & 9,0 bcd & $12,0 \mathrm{ab}$ & $14,0 \mathrm{bcd}$ & $2,3 \mathrm{a}$ & $5,1 \mathrm{ab}$ & $8,5 \mathrm{abc}$ \\
\hline & TRE:CAC & $7,0 \mathrm{~b}$ & $12,0 \mathrm{~b}$ & $11,0 \mathrm{abc}$ & $10,0 \mathrm{~b}$ & $13,0 \mathrm{bcd}$ & $2,5 \mathrm{a}$ & $5,2 \mathrm{ab}$ & $7,3 \mathrm{c}$ \\
\hline \multirow[t]{2}{*}{$20 \mathrm{SA} / 10 \mathrm{~N}$} & TRE:V & $10,0 \mathrm{a}$ & $16,0 \mathrm{a}$ & 10,0 abcd & $11,0 \mathrm{ab}$ & $16,0 \mathrm{a}$ & $2,5 \mathrm{a}$ & $5,3 \mathrm{a}$ & $8,6 a b c$ \\
\hline & TRE:CAC & $8,0 \mathrm{ab}$ & $13,0 \mathrm{~b}$ & $11,0 \mathrm{ab}$ & $11,0 \mathrm{ab}$ & $14,0 \mathrm{bcd}$ & $2,3 \mathrm{a}$ & $5,0 \mathrm{abc}$ & $7,8 \mathrm{~cd}$ \\
\hline \multirow[t]{3}{*}{$30 \mathrm{SA}$} & TRE:V & $4,0 \mathrm{c}$ & $12,0 \mathrm{~b}$ & $9,0 \mathrm{~cd}$ & $11,0 \mathrm{ab}$ & $14,0 \mathrm{bcd}$ & $2,6 \mathrm{a}$ & $4,3 \mathrm{bc}$ & $8,0 \mathrm{bcd}$ \\
\hline & TRE:CAC & $7,0 \mathrm{~b}$ & $12,0 \mathrm{~b}$ & $11,0 \mathrm{abc}$ & $10,0 \mathrm{~b}$ & $13,0 \mathrm{~cd}$ & $2,4 \mathrm{a}$ & $3,7 \mathrm{c}$ & $6,9 \mathrm{~d}$ \\
\hline & CV (\%) & 7,5 & 13,0 & 15,0 & 11,8 & 9,5 & 33,1 & 15,9 & 9,50 \\
\hline
\end{tabular}

Médias seguidas da mesma letra, dentro da coluna, não diferem significativamente, pelo teste de SNK, a 5\% de probabilidade.

$30 \mathrm{~N}=30$ dias na câmara de nebulização;

$10 \mathrm{SA} / 20 \mathrm{~N}=10$ dias na sala de aclimatização e 20 dias na câmara de nebulização;

$15 \mathrm{SA} / 15 \mathrm{~N}=15$ dias na sala de aclimatização e 15 dias na câmara de nebulização;

$20 \mathrm{SA} / 10 \mathrm{~N}=20$ dias na sala de aclimatização e 10 dias na câmara de nebulização;

$30 \mathrm{SA}=30$ dias na sala de aclimatização ;

TRE:V = Terra Roxa Estruturada:Vermicomposto de esterco de bovinos 1:1 (v:v);

TRE:CAC = Terra Roxa Estruturada:Casca de arroz carbonizada 1:1 (v:v). 


\section{CONCLUSÃO}

O enraizamento ex vitro do porta-enxerto de macieira em substrato composto por Terra Roxa Estruturada e Casca de Arroz Carbonizada, simultâneo com a aclimatização, mostrou-se eficiente comparado com o enraizamento in vitro. Os resultados obtidos revelaram que as mudas podem ser repicadas para o substrato contendo casca de arroz carbonizada, serem transferidas por um período de 20 dias na sala de aclimatização e mais 10 dias na câmara de nebulização, antes de serem colocadas em casa de vegetação. Nestas condições, é possível reduzir o tempo e os custos de produção de mudas micropropagadas, pois não são necessários meios de cultura e instalações de laboratório para a indução ao enraizamento, podendo viabilizar economicamente o uso comercial desta tecnologia.

\section{AGRADECIMENTOS}

Agradecemos ao CNPq, pela bolsa de Iniciação científica concedida a acadêmica Scheila C. Maciel; à FINEP, pelo auxílio financeiro para a realização do Projeto Macieira; e ao prof. Antônio Carlos Alves e Paulo Emilio Lovato do CCA/UFSC, pelas sugestões durante a redação deste manuscrito.

\section{REFERÊNCIAS BIBLIOGRÁFICAS}

AVANZATO, D.; CHERUBINI, S. Potenzialitá di radicazione diretta e ambientamento di microtalee di portinnesti di melo moltiplicati in vitro. Rivista di Frutticoltura, v.1, p.87-90. 1993.

BOLAR, J.P.; NORELLI, J.L.; ALDWINCKLE, H.S. An efficient method for rooting and acclimation of micropropagated apple cultivars. HortScience, New York, v.33, n.7, p.1251-1252, 1998.

BRAINERD K.E. ; FUCHIGAMI L.H. Acclimatization of Aseptically cultured apple plants to low relative humidity. Journal of American Society for Horticultural Science, Alexandria, v.106, n.4,p.515-518, 1981.

CAMPOSTRINI, E.; OTONI, W.C. Aclimatação de Mudas: Abordagens Recentes. ABCTP Noticias, CNPH/EMBRAPA, Brasilia, n.25, 12 p., 1996.

DÍAZ-PÉREZ, J.C.; SUTTER; E.G.; SHACKEL, K.A. Acclimatization and subsequent gas-exchange, water relations, survival and growth of microcultured apple plantlets after transplanting them in soil. Physiologia Plantarum, Copenhagen, v.95, n.2, p. 225-232, 1995.

GRIBAUDO, I.; MORTE, M.A.; SCHUBERT, A. Use of gentian violet to differentiate in vitro and ex vitro-formed roots during acclimatization of grapevine. Plant Cell, Tissue and Organ Culture, Netherland, v.41, n.2, p.187-188, 1995.

ICEPA 2000 http://www.icepa.rct-sc.br/produtos/tabprodução/ comparativos.htm

HARBAGE, J. F. ; STIMART, D. P.; AUER, C. pH affects 1hindole-3-butyric acid uptake but not metabolism during the ini- tiation phase of adventitious root induction in apple microcuttings. Journal of American Society for Horticultural Science, Alexandria, v.123, n.1, p. 6-10, 1998.

JAY-ALLEMAND, C.; PENG, S.; CAPELLI, P.; CORNU, D. Micropropagation of hybrid walnut trees. Some factors involved in rooting. Acta Horticulturae, Genebra n. 311, p.117-124, 1992.

LANE, W.D.; MEDOUGALD, J.M. Shoot tissue culture of apple: comparative response of five cultivars to cytokinin and auxin. Canadian Journal of Plant Science, Ottawa, v.62,n.3, p.689-694, 1982.

LÊ C.L.; COLLET G.F. Micropropagation de porte greffe de pommier. Revue Suisse de Viticulture, Arboriculture et Horticiculture, v.23, n.3, p.201-204, 1991.

McCLELLAND, M.T.; SMITH, M.A.L.; CAROTHERS, Z.B. The effects of in vitro and ex vitro root initiation on subsequent microcutting root quality in three woody plants. Plant Cell Tissue and Organ Culture, Dordrecht, v. 23, n.2, p. 115-123, 1990.

MURASHIGUE, T. E.; SKOOG, F. A revised medium for rapid growth and bioassay with tobacco tissue cultures. Physiologia Plantarum, Copenhagen, v.15, n.3, p.473-479, 1962.

NUNES, J.C.O.; BARPP, A.; SILVA, F.C.; PEDROTTI, E.L. Micropropagação do porta-enxerto 'Marubakaido' (Malus prunifolia), a partir da cultura de meristemas. Revista Brasileira de Fruticultura, Jaboticabal, v.21, n.2, p.191-195, 1999.

PEDROTTI, E.L.; VOLTOLINI, J.A. Enraizamento ex vitro e aclimatização dos porta-enxertos de macieira Marubakaido e M9. In: ENCONTROBRASILEIRODEBIOTECNOLOGIA VEGETAL, 2., 1997. Anais... Gramado - RS: FAO-REDBIO, 1997. v. 1, p.67.

POSPÍSLOVÁ J., CATSKÝ J.; SESTÁK Z. Photosynthesis in plant cultivated in vitro, in: Handebook of photosyntesis, Pessarakli (ed.), Nova York (USA), p. 525-540. 1997.

SCHACKEL, K.A.; NOVELLO, V.; SUTTER, E.G. Stomatal function and cuticular condutance in whole tissue-cultured aplle shoots. Journal of American Society for Horticultural Science, Alexandria, v.115,n.3, p.468-472, 1990.

SOKAL, R.R. ROHLF, F.J.Biometry. 3. ed. San Francisco, Freeman and Company, 1995. 776p.

SUTTER E.; Stomatal and Cuticular water loss from apple, cherry, and sweetgum plants after removal from in vitro culture. Journal of American Society for Horticultural Science, Alexandria, v.113, n.2, p.234-238, 1988.

ZIV, M. In vitro acclimatization. In. Automation and environmental control in plant tissue culture., Dordresh, Holland: Kluwer Academic Publishers, 1995, 535p.

ZIMMERMANN, R.H.; FORDHAM, I. Simplified method for rooting apple cultivars in vitro. Journal of American Society for Horticultural Science, Alexandria, v. 110, n.1, p. 34-38. 1985.

WRAIGTH, J.M.; WRAIGHT, K.C. Soil water and root growth. HortScience, Alexandria,v.33, n.6, p.951-959, 1998. 